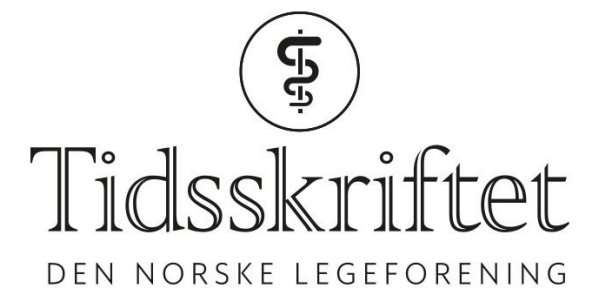

\title{
Fettemboli og koagulasjon
}

KOMMENTAR

STEINAR KRISTIANSEN

E-post: steinarkristiansen@gmail.com

Steinar Kristiansen er lege i spesialisering i anestesi. Ingen oppgitte interessekonflikter.

\section{ERIK WAAGE NIELSEN}

Erik Waage Nielsen er spesialist i anestesi med europeisk intensiveksamen, overlege og professor ved Nordlandssykehuset Bodø, Nord universitet, Universitetene Tromsø og Universitetet i Oslo. Ingen oppgitte interessekonflikter.

Slik vi forstår Dahl og medarbeidere mener de at det er aktiveringen av koagulasjonssystemet som i så stor grad er hovedproblemet ved fettemboliene at embolitypen er uvesentlig (1). Ulike embolityper kan føre til koagulasjon. De kan også aktivere immunforsvaret slik at både komplement- og koagulasjonskaskader aktiveres.

Immunaktivering skjer også ved traumer og kirurgi, og koagulasjonen spiller en viktig rolle ved å avgrense inflammasjonen. Koagulasjonen aktiveres i samspill med de andre kaskadesystemene (2). Den kan skyte over mål føre til disseminert intravaskulær koagulasjon. Det er trolig ikke unikt for fettemboliene. Vi har sett i egne forsøk, både invitro og hos gris at også luftembolier aktiverer komplement og koagulasjon direkte samt gir inflammatorisk lungeskade (3). Da virker det fornuftig å angi embolitype, siden eksempelvis trykkammerbehandling kan være effektiv ved luftembolier.

Dahl og medarbeidere argumenterer for at trombingenerering og inflammasjonsaktivering er nødvendig for at fettceller skal kunne feste seg (1). Men milliarder av små embolier vil kunne blokkere små kar og kapillærer i kraft av å være vanskelig løsbart fett - dette kan trolig ikke unngås selv om koagulasjon eller inflammasjon hemmes. At fettembolisyndrom i tillegg er påvist etter ikke-traumatiske tilstander mener vi gjør det hensiktsmessig å angi embolitypen. Videre indikerer dette at fettembolisyndrom kan være assosiert med, men er distinkt fra, inflammatorisk aktivering etter traume. I en artikkel som vi nå har publisert $\mathrm{i}$ Tidsskriftet, beskriver vi fettembolisyndrom, hvor vi ved histopatologisk farging av hjerne og lunger fant fettembolier og tegn til fettembolisering ved MR cerebrum (4).

Dahl og medarbeidere argumenterer for at det er viktigere å hemme koagulasjon enn å iverksette feil behandling, som for eksempel kortikosteroider. Ingen av delene er vist å være effektivt ved fettembolisyndrom. Det er likevel viktig å erkjenne at cerebrale fettembolier kan gi $\varnothing$ kt intrakranielt trykk, og flere artikler viser at trykkreduserende behandling virker. Det at koagulasjonshemmende behandling som generelt er effektivt etter traumer og ortopedisk kirurgi nettopp ikke er effektiv ved fettembolisyndrom, er kanskje et argument for at fettembolisyndrom er en separat diagnostisk entitet. 
LITTERATUR:

1. Dahl OE, Reikerås O, Pripp AH et al. Fettemboli er en utdatert diagnose. Tidsskr Nor Legeforen 2018. doi: 10.4045/tidsskr.17.0946. [PubMed][CrossRef]

2. Markiewski MM, Nilsson B, Ekdahl KN et al. Complement and coagulation: strangers or partners in crime? Trends Immunol 2007; 28: 184 - 92. [PubMed][CrossRef]

3. Storm BS, Christiansen D, Dybwik K et al. Gas embolism during surgery. A complement mediated condition? Mol Immunol 2017; 89: 193. [CrossRef]

4. Kristiansen S, Madsen MR, Steen R et al. En ung traumepasient med fem frakturer og multiorgansvikt. Tidsskr Nor Legeforen 2018. doi: 10.4045/tidsskr.17.0898. [CrossRef]

Publisert: 12. juni 2018. Tidsskr Nor Legeforen. DOI:10.4045/tidsskr.18.0429

(C) Tidsskrift for Den norske legeforening 2020. Lastet ned fra tidsskriftet.no 